\title{
Sıvılaşma Bölgelerinde Sıvılaşmaz Üst Tabaka Kalınlığının İyileştirme Gereksinimine Etkisi
}

\author{
${ }^{1}$ Sedat Sert, ${ }^{1}$ Aşkın Özocak ve ${ }^{* 1}$ Ertan Bol \\ ${ }^{1}$ Faculty of Engineering, Department of Civil Engineering, Geotechnical Lab., Sakarya University, Turkey
}

\begin{abstract}
Özet
Bu çalışmada Sakarya ili Arifiye ilçesinde inşa edilecek bir fabrika yapısının üzerinde oturacağı sıvılaşabilir ve sıvılaşmaz tabakalar içeren zeminlerde iyileştirmenin gerekli olup olmadığı irdelenmektedir. Alanda önceden yapılmış klasik sondajlı zemin etüt raporunda taşıma gücü ve oturmalar açısından bir problem olmadığı belirtilmekte, ancak kalın bir derinlik boyunca gerçekleşeceği belirtilen sıvılaşmanın önlenmesi için yapı alanının tamamını kapsayacak şekilde iyileştirme yapılmasının gerekli olduğu bildirilmektedir. Bu çalışma kapsamında yürütülen koni penetrasyon deneyleri verilerinin kullanımı ile yapılan analiz ve değerlendirmeler sonucu taşıma gücü ve oturma probleminin olmadığı teyit edilmiş, ancak ortamda üst katmanlarda kalın bir sıvılaşmaz tabakanın bulunması nedeniyle Ishihara Kriteri uyarınca sıvılaşma açısından da zemin iyileştirmesine gerek olmadığı belirlenmiştir.
\end{abstract}

Anahtar kelimeler: Sıvılaşma, zemin iyileştirmesi, Ishihara Kriteri, sıvılaşmaz üst tabaka

\begin{abstract}
In this study, it is investigated whether there is a need to improve the soils, where a factory building will be built on, which contains both liquefiable and non-liquefiable layers, in Arifiye district of Sakarya province. The previously done classical soil investigation report states that there is no problem in terms of bearing capacity and settlements, while soil improvement is reported to be required covering the entire area of the building to prevent liquefaction, which will be carried out over a thick depth. As a result of analysis and evaluations carried out with the use of cone penetration test data, it was confirmed that there was no bearing capacity and settlement problem, but due to the presence of a thick non-liquefiable layer in the upper layers, it was determined that there was no need for ground improvement in terms of liquefaction in accordance with Ishihara criterion.
\end{abstract}

Key words: Liquefaction, soil improvement, Ishihara Criterion, surface non-liquefiable layer

\section{Giriş}

Temeller üzerlerine gelen ve gelebilecek olan yükleri taşıma güçleri aşılmadan ve kabul edilebilir oturmalarla zemine aktaran yapı elemanları olarak tarif edilmektedirler. Statik durum dışında depremler sırasında oluşabilecek zemin sıvılaşması ve yumuşaması durumunda da temellerin bu özelliklerini devam ettirmeleri beklenir [1]. Yapılan zemin incelemeleri ile taşıma gücü, oturma ve sıvılaşma problemlerinin varlığ 1 tespit edilirse zemin iyileştirmesi yapılmas1 gündeme gelebilmektedir.

Sakarya nehrinin taşımış olduğu alüvyonlardan oluşan Adapazarı zeminleri hem yatayda hem de düşeyde büyük değişkenlikler göstermektedir. 1999 depremleri sırasında yer altı su seviyesinin neredeyse yüzeyde bulunduğu kentte farklı bölgelerdeki zeminlerde sıvılaşma, direnç azalması, sürekli temellerde taban kabarması, taşıma gücü kaybı gibi farklı problemler ortaya çıkmış ve bu da büyük miktarda hasar ve can kaybına yol açmıştır [2]. Depremler

*Corresponding author: Address: Faculty of Engineering, Department of Civil Engineering Sakarya University, 54187, Sakarya TURKEY. E-mail address: ebol@sakarya.edu.tr, Phone: +902642955746 
sonrasında yapılan çok sayıda sondaj ve koni penetrasyon deneyi ile kentte farklı derinlik ve kalınlıklarda sıvılaşabilir zeminlerin varlığı yanında gene farklı derinlik ve kalınlıklarda çok s1k1/sert zeminlerin varlığ 1 da tespit edilmiştir [3, 4].

Zamanla yapılan zemin incelemelerinde çeşitli kriterlere göre sıvılaşabilir olduğu belirlenen zeminlerin bulunduğu kesitlerin bazılarında yapı hasarı gözlenirken bazılarında gözlenmemesi bu durumun sorgulanmasına neden olmuştur. Ishihara Kriteri olarak adlandırılan yaklaşımda sıvılaşabilir tabakalar üzerinde belli bir değerden daha kalın sıvılaşmaz tabakanın bulunması durumunda, alttaki zeminlerde sıvılaşma oluşsa bile üst yapı hasarının oluşmayacağı öngörülmektedir [5]. Kısaca yöntem sıvılaşabilir tabakanın üzerinde sıvılaşmayı önleyecek, yani yeterli düzeyde efektif gerilme sağlayacak kalınlık bulunup bulunmadığını denetlemektedir. Şekil 1'de yöntemin uygulanması için kullanılan abak gösterilmektedir [1]. Buna göre herhangi bir ivme değerinde yüzey hasarının oluşmaması için sıvılaşmaz yüzey tabakası kalınlığının eğrinin sağında noktalaması gerekmektedir.
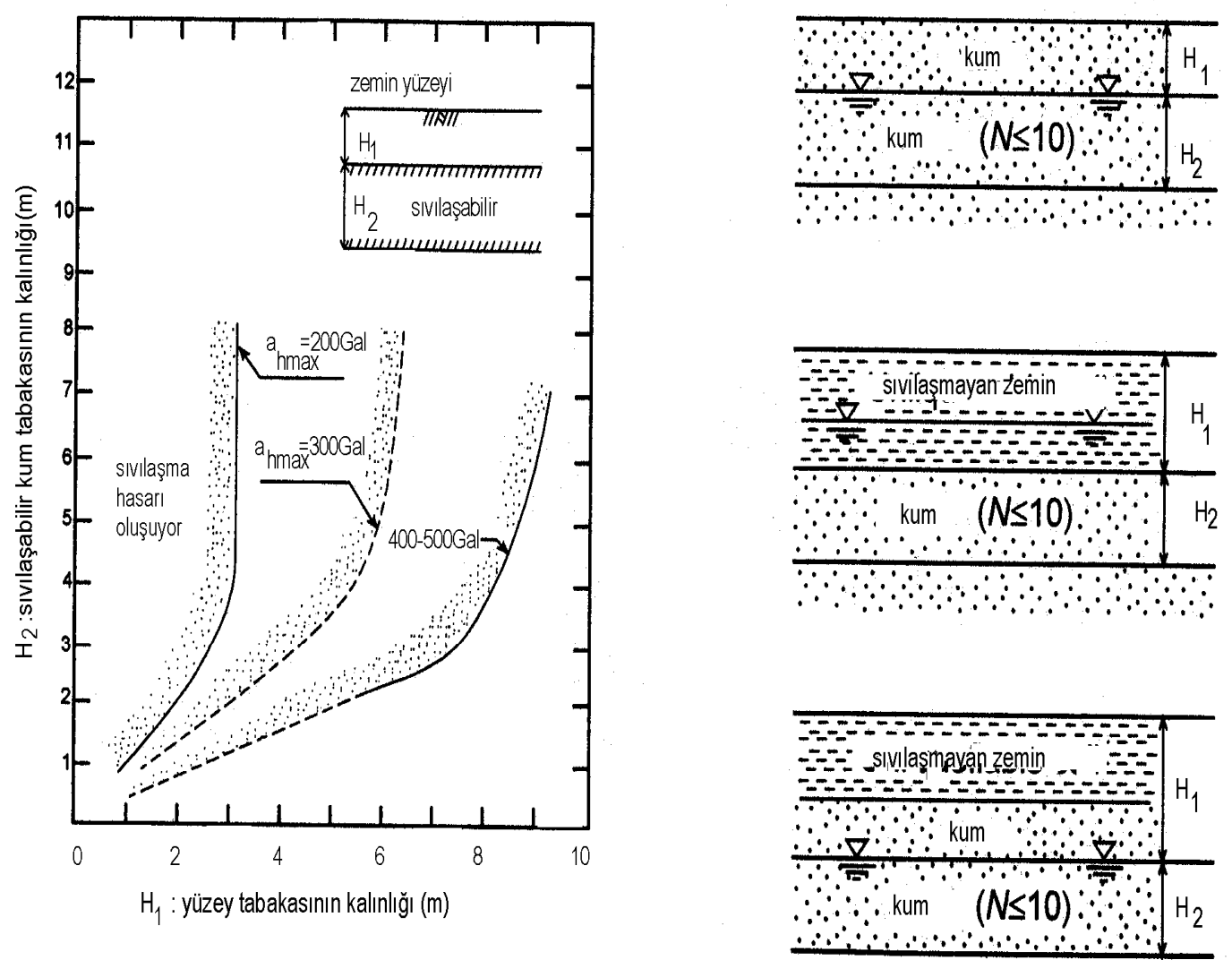

Şekil 1. Ishihara Kriteri

\section{Materyal ve Metot}

Sakarya 1. OSB sınırlarında kalan çalışma alanının yeri Şekil 2'de uydu fotoğrafı üzerinde gösterilmektedir. Yatay bir zemin yüzeyine sahip $4999.55 \mathrm{~m}^{2}$ yüzey alanlı parselde $\mathrm{B}=52.45$ $\mathrm{m}$ ve $\mathrm{L}=53.30 \mathrm{~m}$ olmak üzere yaklaşık $2795 \mathrm{~m}^{2}$ alanlı ayrık nizam işyeri inşaatı yapılacaktır. 


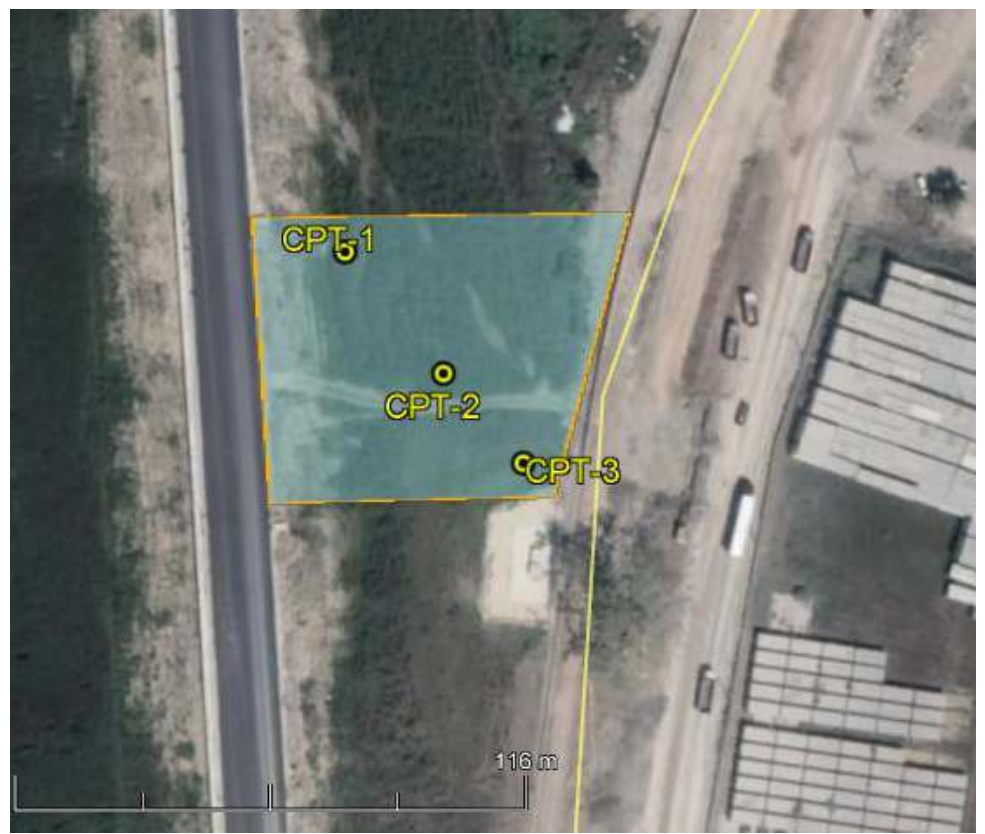

Şekil 2. Çalışma alanının yer bulduru haritası ve CPT noktaları

Fabrika yapısı şerit temellerinin gömme derinliği $1.30 \mathrm{~m}$ olarak planlanmıştır. Bununla birlikte $15.5 \mathrm{~m} \times 17.5 \mathrm{~m}$ boyutlarında aynı gömme derinliğine sahip radye temelli idari bina da bu binaya komşu olarak inşa edilecektir.

$\mathrm{Bu}$ çalışma kapsamında, önceden yapılmış zemin etüdü raporu incelenmiş, gerekli arazi gözlemleri ve CPT çalışmaları yürütülmüş, geoteknik analizler sonucu jeolojik ve geoteknik değerlendirmeler yapılarak söz konusu yapı inşasına yönelik zemin özellik ve parametreleri belirlenmiştir.

İnceleme alanında özel bir firma tarafından yürütülen çalışma ile hazırlanmış Ağustos 2017 tarihli rapordan alanda 6 noktada sondaj kuyusu açıldığı anlaşılmaktadır. Güncel çalışmada ise Sakarya Üniversitesi'nin sahip olduğu boşluk suyu basınçlarının da okunduğu koni penetrasyon deney makinesi ile alanda 3 noktada PCPT deneyleri gerçekleştirilmiştir. Arazide yapılmış sondalama noktaları koordinatları ile YASS değerleri Tablo 1'de verilmektedir.

Tablo 1. Sondalama noktaları koordinatları

\begin{tabular}{ccccc}
\hline PCPT No & Enlem (N) & Boylam (E) & Derinlik (m) & YASS (m) \\
\hline PCPT-1 & $40.726105^{\circ}$ & $30.410967^{\circ}$ & 17.64 & 3.50 \\
PCPT-2 & $40.725857^{\circ}$ & $30.411232^{\circ}$ & 16.70 & 3.50 \\
PCPT-3 & $40.725674^{\circ}$ & $30.411447^{\circ}$ & 17.68 & 4.00 \\
\hline
\end{tabular}

Arazide daha önceden yapılmış sondajlı zemin inceleme raporuna göre; ortam zeminlerinin üst 6.00-9.00 metresinin orta plastisiteli killerden oluştuğu anlaşılmaktadır. SAÜ tarafından bu çalışma kapsamında yürütülen sondalama verilerine göre ise 6.30 metre kalınlığa kadar bu killer belirmektedir. Daha sonra kalınlığ 1 metreyi $(6.30-7.30 \mathrm{~m})$ bulan kumlar kesilmiş ve sonra yine killere girilmiştir. Bu kilin kalınlığı 3.00 metreyi bulmakta $(7.30-10.30 \mathrm{~m})$ ancak tam ortasında ince bir silt tabakası yer almaktadır. Daha sonra 1.00-1.50 metre kalınlığında (10.30-11.50 m) kum tabakası kesilmiş ve bunun altında tekrar killere geçiş yapılmış olup kuyu sonuna kadar benzer şekilde killerin varlığı devam etmiştir. Yer altı su seviyesinin de 
3.50-4.00 m civarında olduğu anlaşılmıştır. Şekil 3'de PCPT-1 deneyinden elde edilen sondalama logu, Şekil 4'te ise PCPT-2 ve PCPT-3 noktalarında deney çalışmalarının fotoğrafı görülmektedir.

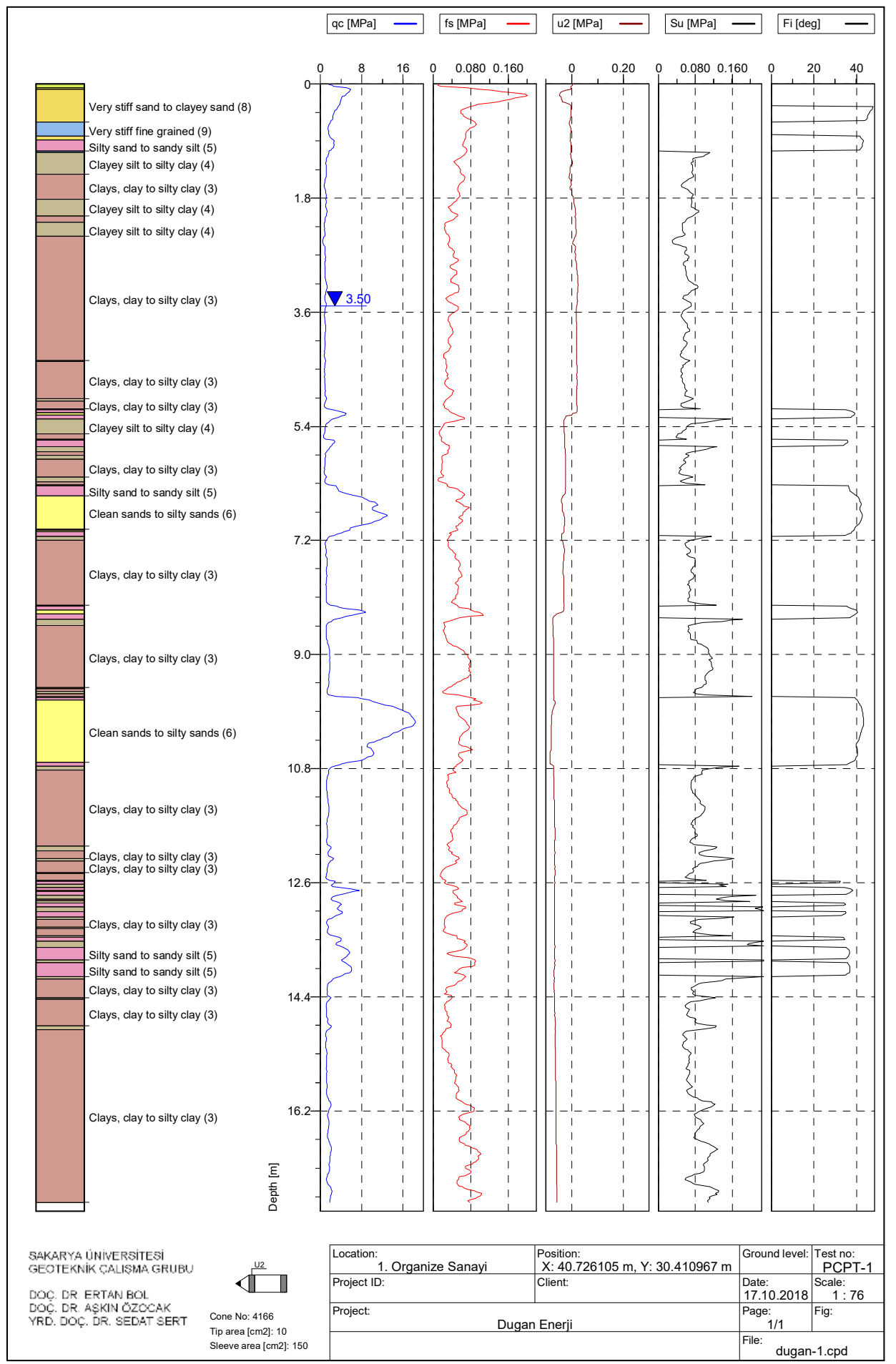

Şekil 3. PCPT-1 sondalama logu 

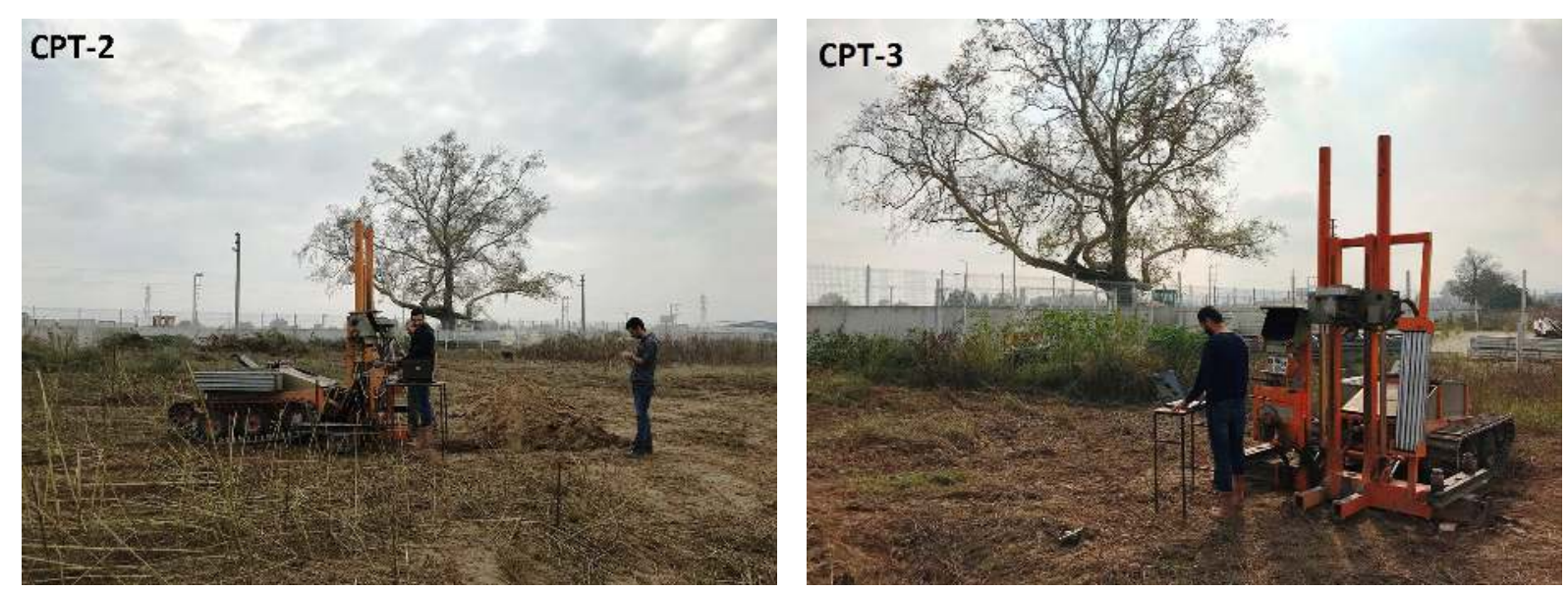

Şekil 4. CPT-2 ve CPT-3 deneylerinden görüntüler

\section{ANALİZLER}

\subsection{Taşıma gücü ve konsolidasyon analizi}

İşveren tarafından sağlanan ve statik ve deprem durumunu içeren üst yapı çözümlerinden elverişsiz durumu gösteren taban basıncı dağılımları şerit temeller için Şekil 5'de, radye temel için ise Şekil 6' da sunulmuştur.

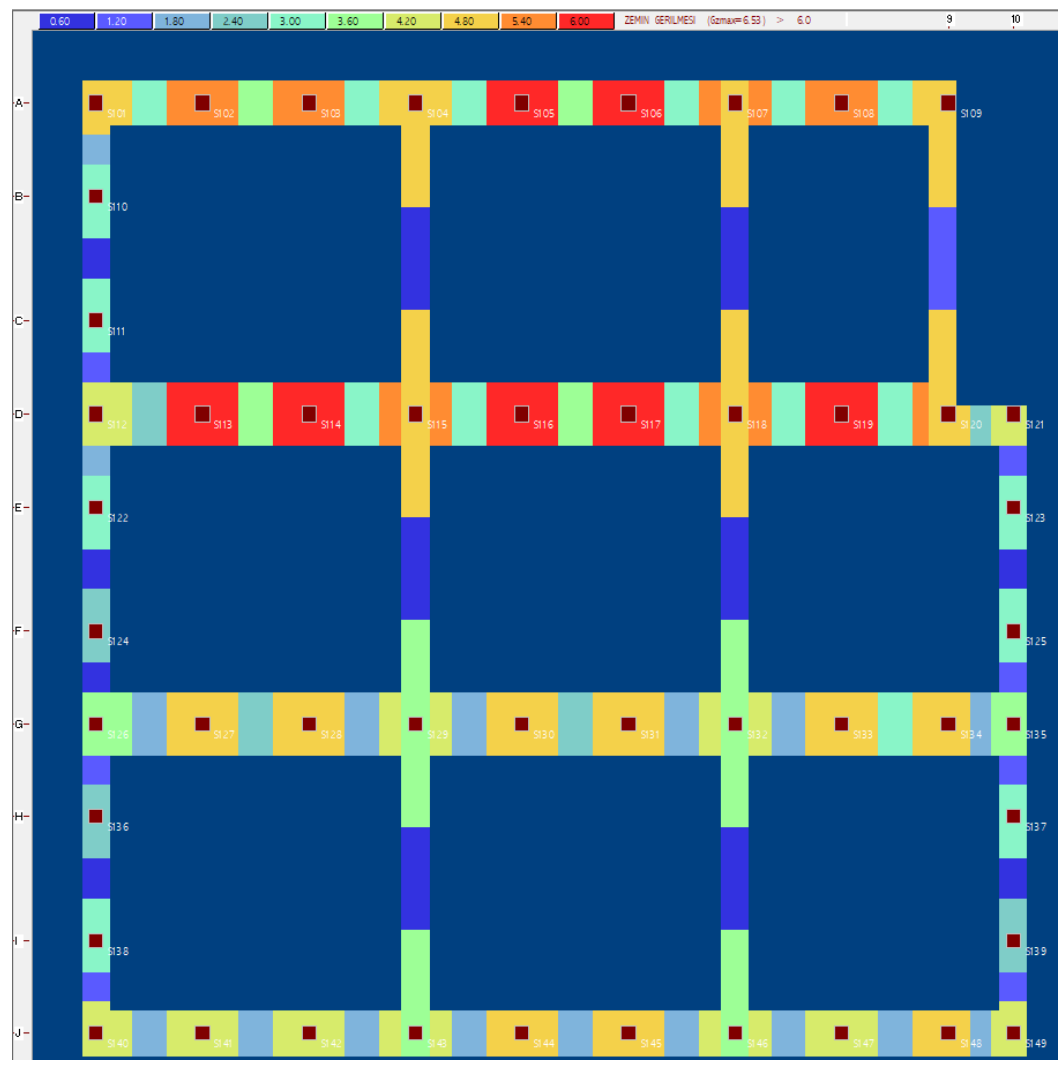

Şekil 5. Şerit temel altında taban basıncı dağılımları 


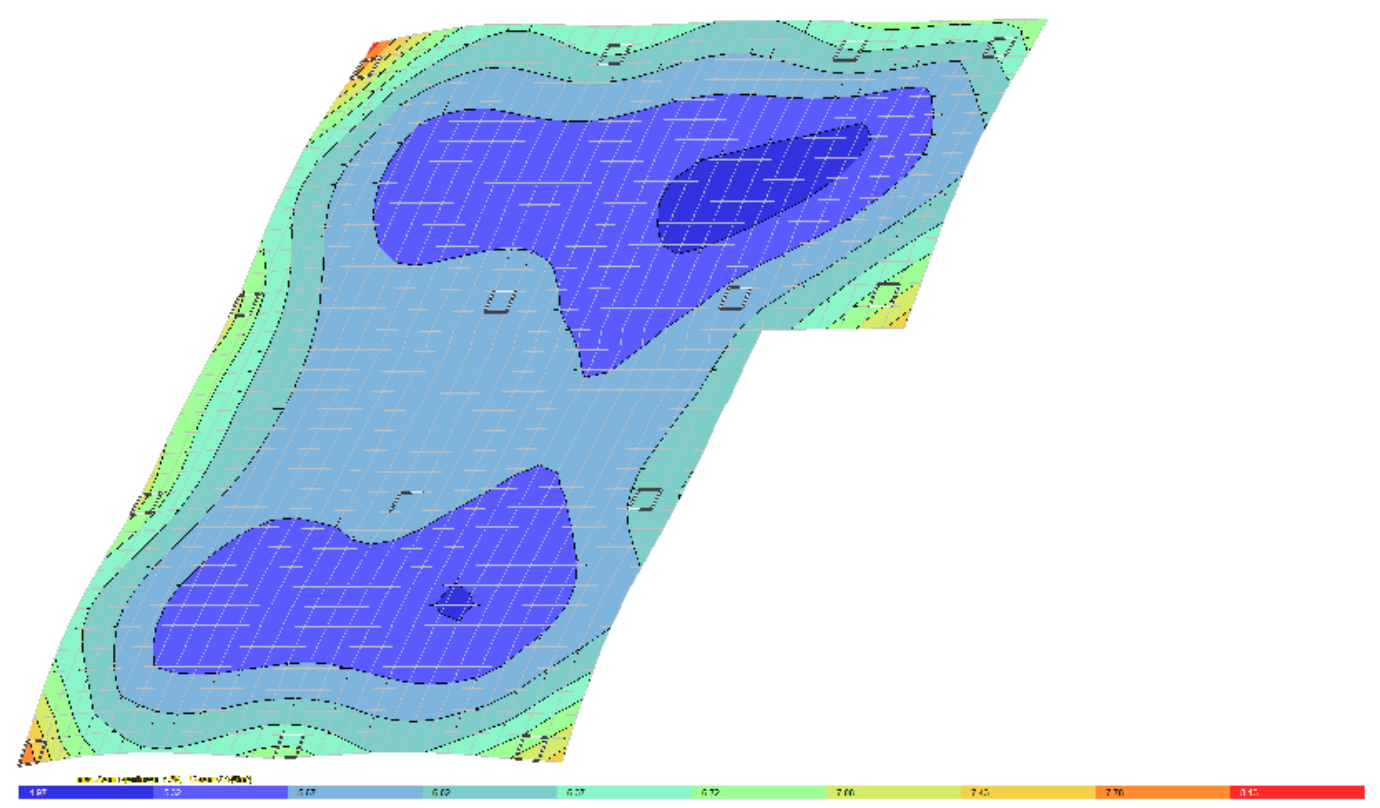

Şekil 6. İdari bina yayılı temeli altında taban basıncı dağılımları

Koni penetrasyon deneyi $(C P T)$ verileri kullanılarak drenajsız kayma direnci $\left(c_{u}\right)$ Eşitlik 1 ile hesaplanabilmektedir.

$$
\mathrm{c}_{\mathrm{u}}=\left(\mathrm{q}_{\mathrm{c}}-\sigma_{\mathrm{o}}\right) / \mathrm{N}_{\mathrm{k}}
$$

Burada $N_{k}$ koni faktörü olup Önalp ve diğ. (2006), Adapazarı zeminleri için $N_{k}$ değerini 14.55 olarak bulmuşlardır [6].

Fabrika yapısının şerit temellerinin 1.30 metreye oturtulacağı ve temel genişliği kadar bir derinliği etkileyeceği düşüncesi ile CPT verilerinden elde edilen drenajsız kayma direnci $\left(c_{u}\right)$ değerleri bu kısım göz önüne alınarak ortalama olarak hesaba katılmıştır. Söz konusu derinlik boyunca (1.30-5.00 m arasi) drenajsız kayma direncinin $\left(c_{u}\right)$ ortalama $65 \mathrm{kPa}$ civarlarında olduğu anlaşılmıştır (Şekil 3).

Şerit temellerde drenajsız koşullarda $\left(\phi_{u}=0\right)$ taşıma gücü Eşitlik 2'de verilen Skempton formülü ile hesaplanabilmektedir [7]. Burada GS güvenlik sayısını temsil etmekte olup genellikle 3 civarında kabul edilerek hesaplar yapılmaktadır.

$$
\sigma_{\mathrm{em}, \text { net }}=\left(\mathrm{c}_{\mathrm{u}} \mathrm{NN}_{\mathrm{c}}\right) / \mathrm{GS}
$$

Buna göre Skempton yöntemi kullanılırsa farklı boyutlardaki ( $B=2.50 \mathrm{~m}$ ve $B=3.50 \mathrm{~m})$ şerit temeller için taşıma gücü katsayısı $N_{c}$ sırası ile 6.00 ve 5.70 olarak bulunmaktadır (Şekil 7). Buradan net taşıma güçleri de:

$\mathrm{B}=2.50 \mathrm{~m}$ olan bir şerit temel için $\sigma_{e m_{(n e t)}}=\frac{65 \cdot 6}{3}=130 \mathrm{kPa}$ ve

$\mathrm{B}=3.50 \mathrm{~m}$ olan bir şerit temel için $\sigma_{e m_{(n e t)}}=\frac{65 \cdot 5.7}{3}=123.5 \mathrm{kPa}$ olarak alınabilir. 


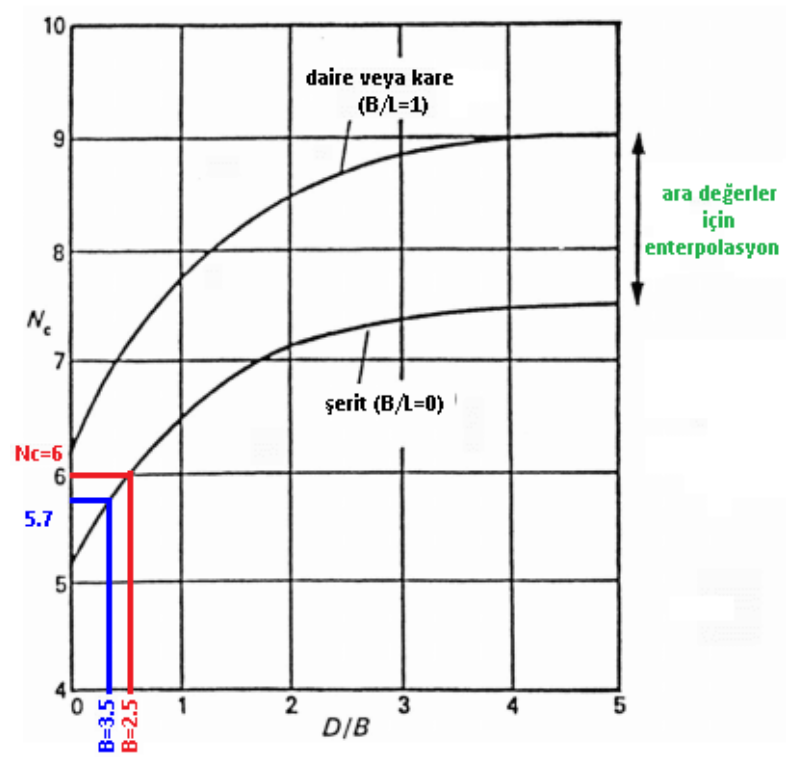

Şekil 7. Killi zeminde Skempton taşıma gücü katsayısı

İdari bina kısmında ise radye temelin gömme derinliği yine $1.30 \mathrm{~m}$ olarak planlanmıştır. PCPT verilerine göre drenajsız kayma direnci alt taraftaki killerde daha da yüksek olmasına rağmen, burada güvenli tarafta kalınarak $65 \mathrm{kPa}$ olarak alınmıştır. $\mathrm{Bu}$ durumda yayılı temel için güvenli net taşıma gücü 3 güvenlikle Eşitlik 3 [8] kullanılarak,

$$
\begin{aligned}
& \sigma_{e m_{(n e t)}}=1.713 \cdot c_{u}\left(1+\frac{0.195 \cdot B}{L}\right)\left(1+0.4 \frac{D_{f}}{B}\right) \\
& \sigma_{e m_{(n e t)}}=1.713 \cdot 65 \cdot\left(1+\frac{0.195 \cdot 15.5}{17.5}\right)\left(1+0.4 \frac{1.30}{15.5}\right) \approx 135 \mathrm{kPa}
\end{aligned}
$$

gibi söz konusu idari yapı taban gerilmeleri için yeterli bir düzeyde hesaplanmaktadır.

Zemin kesitine bakıldığında yapı temelleri altında killi birimlerin yer aldığı, $6 \mathrm{~m}$ derinlikten sonra killi siltli tabakalara girildiği anlaşılmaktadır. Statik-dinamik hesaplamalar sonucunda bina en büyük gerilmesinin $70 \mathrm{kPa}$ ' geçmeyeceği rapor edilmiştir. Bu durumda hafif derecede aşırı konsolide olduğu bilinen ortamda son oturma Eşitlik 4 yardımıyla;

$$
S_{\infty}=H_{0} \frac{C_{r}}{1+e_{0}} \log \frac{\bar{\sigma}_{o}+\Delta \sigma}{\bar{\sigma}_{o}}
$$

$50 \mathrm{~mm}$ gibi yapının tolere edebileceği bir değerde olacaktır.

\subsection{Stvılaşma ve afet riski}

Öncelikle belirtilmelidir ki çalışma alanı jeolojik ve jeomorfolojik özellikleri nedeniyle heyelan, kaya düşmesi gibi doğal afetlere maruz olmayıp, yaklaşık 20-30 yıllık aralıklarla beliren $M=6.5-7.5$ 'lik deprem riskiyle karşı karşıyadır. İstatistiklere bakıldığında depremin önümüzdeki yıllarda olma olasılığı oldukça yüksektir. Bu nedenle yapı temellerinin $a_{h}=0.4 g$ gibi bir yatay ivme alacağı hatırda tutulmalıdır. Yakın geçmişe kadar sıvılaşmaya yönelik 
zemin incelemeleri genellikle sondaj sırasında yapılan standart penetrasyon (SPT) deney sonuçlarına dayandırılmakta idi. Bugün de durumun fazlaca değiştiği söylenememektedir. Sondajlarda SPT deneyleri ile sağlanan darbe sayıları yanında, elde edilen örselenmiş numunelerden ortamın fiziksel, ayrıca alınacak örselenmemiş numunelerden de mekanik özellikleri tayin edilmeye çalışılmaktadır. Bununla birlikte, gelişen teknoloji ile boşluk suyu basınçlarının da ölçülebildiği koni penetrasyon deneyi (PCPT) birçok ülkede önemli bir uygulama alanı bulmuş ve geleneksel yöntem olarak kabul edilen standart penetrasyon deneyinin (SPT) yerini almaya başlamıştır.

Sıvılaşabilir kumların tanımlanmasında SPT ve CPT deney verilerinin kullanımı sürmekte olup bu yaklaşımda çoğunlukla çevrimsel gerilme oranını yansıtan CRR/CSR değeri kullanmakta ve yöntem bu nedenle kumlarla sinırlanmaktadır.

Son y1llarda CPT deneyi kesintisiz okuma alabilmesi, güvenilirlik ve tekrar edilebilirliğinin yüksek olmasından dolayı CRR'1 tahmin etmede daha popüler olmuştur. Korelasyon aşağıdaki basitleştirilmiş denklemlerle verilmiştir [9].

$$
\begin{array}{ll}
50<\left(\mathrm{q}_{\mathrm{c} 1 \mathrm{~N}}\right)_{\mathrm{cs}} \leq 160 \text { için } & C R R_{7.5}=93\left[\frac{\left(q_{c 1 N}\right)_{c s}}{1000}\right]^{3}+0.08 \\
\left(\mathrm{q}_{\mathrm{clN}}\right)_{\mathrm{cs}}<50 \text { için } & C R R_{7.5}=0.833\left[\frac{\left(q_{c 1 N}\right)_{c s}}{1000}\right]+0.05
\end{array}
$$

Sonuçta sıvılaşmaya karşı direnç Eşitlik 6 ile bulunur;

$$
F S=\frac{C R R_{7.5}}{C S R} M S F
$$

Bunun yanında, Iwasaki ve ark. (1978)'nın geliştirdiği, sıvılaşma potansiyelinin tahmini için sıvılaşma potansiyel indisi (LPI) yöntemi mevcuttur [10]. Bu yönteme göre, sıvılaşmanın büyüklüğü sıvılaşan tabaka kalınlığına, bunun yüzeye olan yakınlığına ve sıvılaşmaya direncin deprem tarafından beliren yüke oranını ifade eden güvenlik katsayısının birden küçük olduğu orana bağlıdır. Burada FS sıvılaşmaya karşı direncin deprem tarafından beliren yüke oranını göstermektedir. $20 \mathrm{~m}$ 'den daha büyük derinliklerde oluşacak sıvılaşmanın etkisinin yüzeyde çok nadir belireceği gerekçesiyle araştırmacılar, LPI' nın hesabını 0 ile 20 $\mathrm{m}$ arasında sınırlandırmışlar ve Eşitlik 7'yi önermişlerdir.

$$
L P I=\int_{0}^{20 m} F w(z) d z
$$

Burada z metre boyutunda derinlik, w ise derinlik ağırlık faktörü olmak üzere;

$$
\begin{aligned}
& \mathrm{FS} \leq 1 \text { için } \mathrm{F}=1-\mathrm{FS} \\
& \mathrm{FS}>1 \text { için } \mathrm{F}=0 \\
& \mathrm{w}(\mathrm{z})=10-0.5 \mathrm{z}^{\prime} \text { dir. }
\end{aligned}
$$


Buradan, bulunan LPI değerinin Tablo 2'de verilen aralıklarına göre sıvılaşma potansiyelinin büyüklüğü tahmin edilebilmektedir. Sıvılaşmanın tipik olarak LPI değerinin 5 değerini aştığ durumlarda gerçekleştiği belirtilmektedir [11].

Tablo 2. Sıvılaşma Potansiyel İndisine göre sıvılaşmanın şiddeti

\begin{tabular}{cc}
\hline Sıvılaşmanın şiddeti & LPI \\
\hline Az-yok & LPI $=0$ \\
Küçük & $0<$ LPI $<5$ \\
Orta & $5<$ LPI $<15$ \\
Büyük & $15<$ LPI \\
\hline
\end{tabular}

$\mathrm{Bu}$ çalışma kapsamında tüm CPT'lerde sıvılaşma analizleri yukarıda anlatılan çevrimsel gerilme yöntemine göre yapılmış ve her sondalamada sıvılaşma potansiyeli indisi tayin edilmiştir. Şekil 8'de PCPT-1 noktası için yapılan analiz sonuçları görülmektedir. Şekil 8'de ilk üç sütundaki grafikler arazide ölçülen uç direnci $\left(q_{c}\right)$, çevre sürtünmesi $\left(f_{s}\right)$ ve boşluk suyu $\left(u_{2}\right)$ basınçlarını göstermektedir. Sonraki iki sütun bu parametrelerden türetilmiş ince daneli zeminler için drenajsız kayma direnci $\left(c_{u}\right)$ ve iri daneli zeminler için kayma direnci açısını $(\phi)$ göstermektedir. Daha sonraki sütunlar sıvılaşma analizi için çıkartılmış gerekli parametreleri göstermektedir. Burada en önemli parametre $q_{c l N c s}$ ve $I_{c}$ 'dir. $q_{c l N c s}$ zeminin sıvılaşmaya karş1 olan direncini, $\mathrm{I}_{\mathrm{c}}$ ise zeminin cinsini göstermektedir. $q_{c 1 N c s}$ 'nin 160 'dan büyük olması iri daneli zeminin sıvılaşmaz olduğunu ifade etmektedir. Bununla birlikte; $I_{c}$ 'nin 2.6'dan büyük olması da zeminin kil bakımından zengin, yani sıvılaşmaz nitelikte olduğunu göstermektedir. $\% F$ sütunu normalleştirilmiş sürtünme oranıdır ve bazı araştırıcılar bu oranın \% 1 'den fazla olması durumunda sıvılaşmanın gerçekleşmeyeceğini savunmaktadırlar. $\% F C$ sütunu görünür ince dane oranını temsil etmektedir. Killi birimlerde oranın yükseldiği dikkate değerdir. $C R R$ $C S R$ sütunu çevrimsel gerilme oranının hesaplandığı ve grafik olarak sunulduğu kısımdır. Sıvılaşan tabakaların bir nevi kümülatif toplamı LPI grafiği ile verilmektedir. Daha sonra sıvılaşabilir tabakaların derinlik ve kalınlıklarını gösteren grafikler bulunmaktadır [9, 12]. Son iki sütunda ise zemin sınıfları gösterilmektedir [9].

Şekil 8'de detayları verilen analiz sonuçları incelendiğinde zemin kesitinde özellikle ilk 6.00 m'nin sıvılaşmaz killerden oluştuğu anlaşılmaktadır. Robertson\&Wride (1998) kriterine göre değerlendirme yapıldığında; 5.00-6.00 metreden sonra farklı derinliklerde ancak kısıtlı kalınlıklarda sıvılaşma potansiyeli taşıyan kumlu-siltli tabakalar yer almaktadır (Tablo 3) [9]. Tablo 2'ye göre orta derecede sıvılaşma potansiyeline sahip kesitlerde, sıvılaşır zeminlerin üzerinde kalın bir sıvılaşmaz tabakanın olması nedeniyle burada Ishihara Kriterini kullanmak gereklidir. Buna göre en yakın sıvılaşır tabakanın derinlikleri göz önüne alınmış ve sıvılaşır tabakaların toplam kalınlığı (Tablo 3) grafiğe noktalanmıştır (Şekil 9). Sonuç olarak olası depremde söz konusu tabakaların sıvılaşmaları durumunda bile yüzeyde bir hasar oluşturmayacağı kanaatine varılmıştır.

Tablo 3. Sıvılaşma analizleri özeti

\begin{tabular}{ccccccc}
\hline $\begin{array}{c}\text { PCPT } \\
\text { No }\end{array}$ & $\begin{array}{c}\text { Derinlik } \\
(\mathrm{m})\end{array}$ & $\begin{array}{c}\text { YASS } \\
(\mathrm{m})\end{array}$ & LPI & $\begin{array}{c}\text { Sivılaşmanın } \\
\text { Şiddeti }\end{array}$ & $\begin{array}{c}\text { Yüzey Tabakası } \\
\text { Kalınlığ }(\mathrm{m})\end{array}$ & $\begin{array}{c}\text { Sivılaşabilir Katman } \\
\text { Kalınlığ }(\mathrm{m})\end{array}$ \\
\hline PCPT-01 & 17.64 & 3.50 & 7.48 & Orta & 5.10 & 1.48 \\
PCPT-02 & 16.64 & 3.50 & 7.28 & Orta & 5.36 & 1.10 \\
PCPT-03 & 17.62 & 4.00 & 5.80 & Orta & 5.66 & 0.94 \\
\hline
\end{tabular}




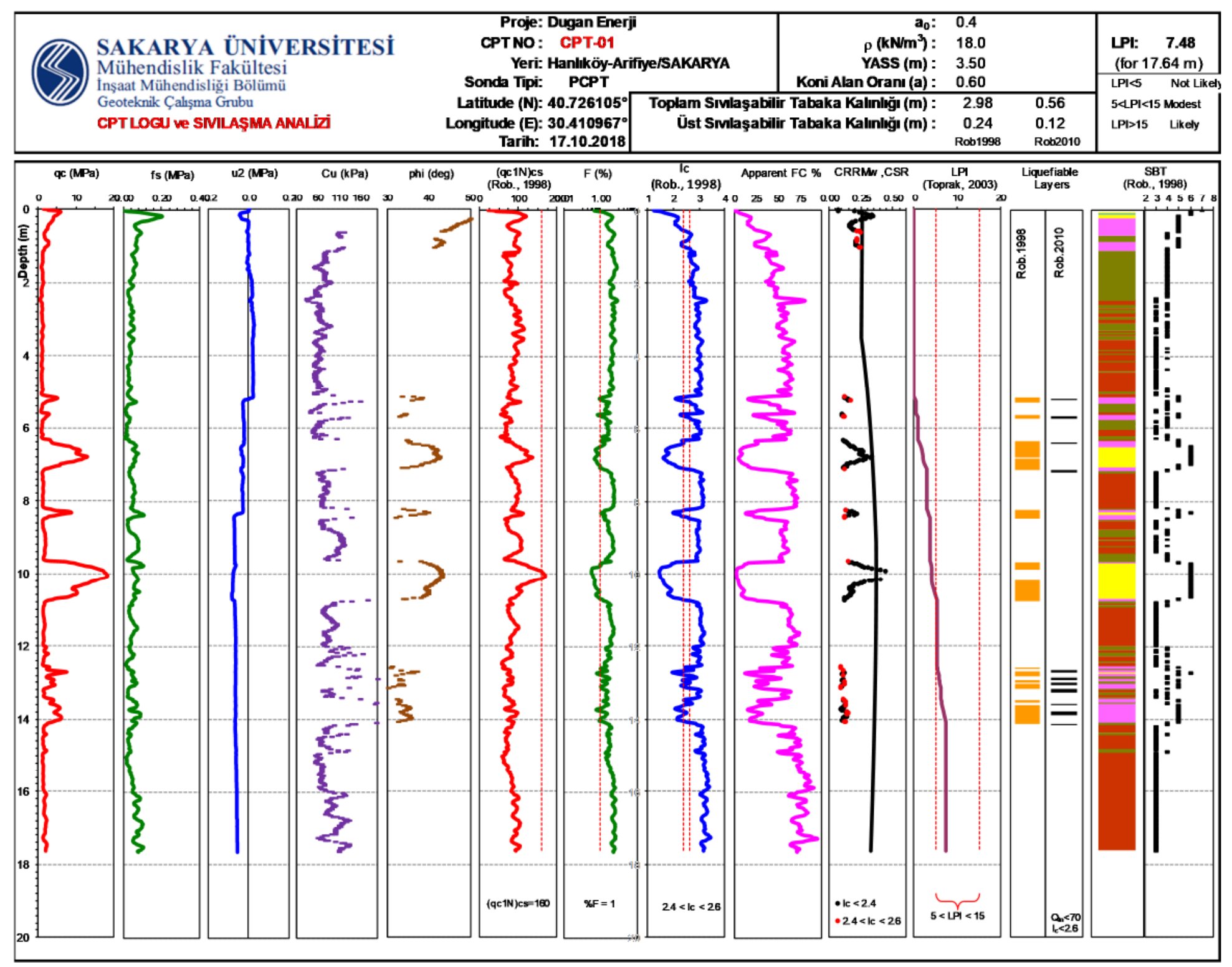

Şekil 8. PCPT-1 değerlendirmesi ve sıvılaşma analizi 


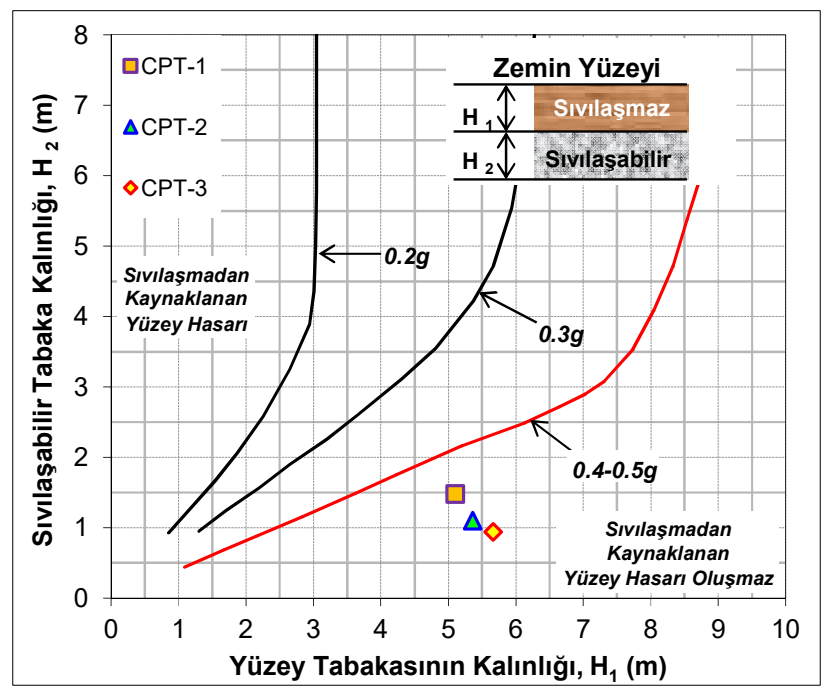

Şekil 9. Sıvılaşır tabakaların yüzeye etkisi [5]

\section{Sonuç ve Öneriler}

CPT verileri ile yapılan analizler sonucunda temel tabanı altında farklı derinliklerde sıvılaşma potansiyeli taşıyan kısıtlı kalınlıkta zeminlerin bulunduğu bir ortamda üst katmanlardaki kalın sıvılaşmaz tabakaların etkisiyle söz konusu tabakaların sıvılaşmaları durumunda bile Ishihara Kriterine göre yüzeyde bir hasar oluşmayacağı kanaatine varılmıştır. Çalışma ile parselde önceki klasik zemin inceleme raporunun aksine bir zemin iyileştirmesine gerek olmadığı gösterilmiştir.

Parselde inşası planlanan sanayi yapısı için temel taşıma güçleri yeterli görünmektedir. Ancak kren yükleri de düşünülerek temel taşıma güçleri artırılmak istenilebilir. Buna yönelik olarak, sürekli temellerin inşaası öncesinde doğal zeminin temel genişliğinde temel alt kotundan $1 \mathrm{~m}$ kadar kazılıp yerine dane büyüklüğü $10 \mathrm{~cm}$ 'yi geçmeyen kaliteli dolgu gerecinin optimum su muhtevasında max. 40 cm' yi geçmeyen tabakalar halinde sıkıştırılması gereklidir. Doğal zeminle dolguyu ayırmak için dolgu öncesinde kazı tabanında geotekstil-geogrid kullanılabilir. Geotekstil ve geogrid kombinasyonunun yapılacak kontrollü dolgu tabakaları arasında tekrarlanması temel gömme derinliğine kadar zemin niteliğini artıracak bir uygulama olacaktır. Bu durumda kullanılacak dolgu malzemesinin uygunluğunun laboratuvar verileri ile teyit edilmesi ve sıkıştırılan tabakaların arazide kontrolünün mutlaka yapılması önem taşıyacaktır. 


\section{Kaynaklar}

[1] Önalp A, Sert S. Geoteknik Bilgisi 3 Bina Temelleri: Güncellenmiş 3. Baskı. İstanbul, Birsen Yayınevi, 2016, $445 \mathrm{~s}$.

[2] Önalp A, Arel E, Bol E. A general assesment of the effects of 1999 earthquake on the soilstructure interaction in Adapazarı, jubilee papers in honour of Prof. Dr. Ergün Toğrol (Editors: A. Sağlamer, K. Özüdoğru, S. Gök, A. Kurtuluş), Istanbul, Turkey, ITU Press (2001), p. 76-89.

[3] Sert S. Aluviyal ortamda kazıklı yayılı temellerin üç boyutlu analizi, Doktora Tezi, SAÜ FBE, Adapazarı, 2003, 137 sayfa.

[4] Sert S, Bol E. Adapazarı zeminlerinde saglam katman derinlikleri. TMMOB İnşaat Mühendisleri Odası Adana Şubesi Geoteknik Sempozyumu, Adana, 2005, 239-251.

[5] Ishihara K. Stability of natural deposits during earthquakes. Proc.XI.ICSMFE, 1985, 1:321.

[6] Önalp A, Bol E, Ural N. Estimation of undrained shear strength from cone tip resistance in clayey soils, Proceedings of Seventh International Congress on Advances in Civil Engineering, Y1ldız Technical University, İstanbul, Turkey, 2006, p. 1-12.

[7] Skempton, A.W., The $\phi_{\mathrm{u}}=0$ analysis for stability and its theoretical basis, Second Int. Conf. of Soil Mech. and Found. Engrg,. 1948; 1: 72-77.

[8] Das BM. Principles of foundation engineering. Cengage Learning, 7th ed., 2015, 796 p.

[9] Robertson PK, Wride C. Evaluating cyclic liquefaction potential using the cone penetration test. Canadian Geotechnical Journal 1998; 35:442-459. http://dx.doi.org/10.1139/t98-017

[10] Iwasaki T, Tokida K, Tatsuko $\mathrm{F}$ and Yasuda S. A practical method for assessing soil liquefaction potential based on case studies at various site in Japan, $2^{\text {nd }}$ International Conference on Microzonation, San Francisco 1978, p. 885-896.

[11] Toprak S, Holzer TL. Liquefaction potential index: field assessment, J. of Geotechnical and Geoenvironmental Engineering, ASCE 2003; 129: 4: 315-322.

[12] Robertson PK. Soil behaviour type from the CPT: an update 2nd International Symposium on Cone Penetration Testing, Huntington Beach, 2010; 2:575-583. 